\title{
ALGUMAS INOVAÇõES DO ANTEPROJETO DE CÓDIGO DE PROCESSO CIVIL
}

\author{
JOSÉ CARLOS BARBOSA MOREIRA * \\ (Docente Livre de Direito Judiciário Civil nas Faculdades de Direito das \\ Universidade Federal do Rio de Janeiro e Estadual da Guanabara.)
}

Os momentos, como o atual, de reformulação legislativa não podem deixar de suscitar, principalmente entre aquêles a quem toca $\circ$ exercício de atividades ligadas, de maneira mais direta, com a interpretação e a aplicação do direito objetivo, o interêsse no confronto entre a normatividade que declina e a normativa que desponta. Sem êsse indispensável trabalho comparativo dificilmente se chega à plena compreensão do nôvo texto, quando não se renuncia pura e simplesmente a explorar-lhe as virtualidades.

A leitura do Anteprojeto de Código de Processo Civil, elaborado por essa figura eminentíssima da nossa ciência processual que é o Professor ALFREDO BUZAID, revela a consagração de não poucos institutos desconhecidos do diploma de 1939, ainda em vigor. Não é nosso propósito inventariá-los de forma exaustiva. Menos ainda aspiramos, é claro, a investigar em profundidade, aqui, o sentido e o alcance de que se possa revestir a entronização de cada qual no direito positivo brasileiro. Será tarefa para um livro, ou vários, jamais para uma palestra que anseia por evitar a todo custo, pelo menos, o defeito da excessiva prolixidade...

Outro programa, conquanto bem mais modesto, pareceu-nos interessante. $\mathrm{Na}$ extensa temática que se nos apresentava, escolhemos, para objeto destas ligeiras considerações, três dos novos institutos acolhidos no Anteprojeto, os quais, sem detrimento de outros, pensamos merecer a atenção dos estudiosos, quer pela significação teórica, quer pela importância prática que todos, sem dúvida, assumem. São êles: a ação declaratória incidental, o "recurso adesivo" e a tentativa de conciliação.

2 - A ação declaratória incidental é instituto cuja razão de ser se liga intimamente ao problema dos limites objetivos da coisa julgada. Não raro acontece que, para formar sua convicção sôbre a 
procedência ou a improcedência do pedido, precisa o juiz resolver questão referente à existência ou inexistência de relação jurídica ou status, de que se acha o direito postulado em dependência lógica necessária: assim, por exemplo, quando, em processo de ação de alimentos, se põe em dúvida o parentesco entre as partes, indicado pela lei civil com um dos pressupostos do nascimento da obrigação alimentar; ou quando alguém reclama em juízo o pagamento de multa convencional por suposta violação de contrato, e surge controvérsia acêrca da validade do próprio negócio jurídico. É o fenômeno da prejudicialidade, cuja manifestação, aliás, não se limita ao âmbito do mérito, embora se revista aí, como é óbvio, de maior relevância prática.

A tendência hoje universalmente dominante, quer na doutrina, quer na legislação mesma, é a de excluir a solução de tais questões, ditas prejudiciais, do terreno coberto pela autoridade da coisa julgada. Forma-se esta, únicamente, sôbre a conclusão última do órgão judicial, relativa ao direito postulado, sem alcançar as proposições firmadas como razões de decidir, entre elas as que exprimem o convencimento do juiz sôbre as questões lògicamente condicionantes da principal. Essas proposições, embora já não se possam discutir, daí em diante, com o objetivo de contestar o resultado do processo - por fôrça daquilo a que MACHADO GUIMARÃES chamou recentemente a "eficácia preclusiva pan-processual da coisa julgada" $\left.{ }^{1}\right)$-, não recebem contudo em si mesmas o sêlo de incontrovertibilidade que thes imprimiria, se as abrangesse, a auctoritas rei iudicałae, e para qualquer outro fim permanece aberta a respectiva apreciação, em processo subseqüente. O trânsito em julgado da condenação a prestar alimentos $\left(^{2}\right)$ não impede que se venha depois a decidir com tôda a liberdade acêrca do parentesco, e eventualmente a negá-lo; o trânsito em julgado da condenação à multa contratual não obsta a que mais tarde se proceda sem qualquer restrição à valoração do contrato, para concluir-se talvez pela declaração da respectiva nulidade.

Êsse é, também, de lege lała, entre nós, o entendimento que nos parece verdadeiro. Não ignoramos a tendência, que aliás já

(1) - Preclusão, coisa julgada, efeito preclusivo, in Estudos de Direito Processual Civil, Rio S. Paulo, 1969, págs. $15 / 16,23,32$.

(2) - Escolhemos de caso pensado o exemplo para marcar nossa posição crítica ante a redação do art. 15 d aLei n.o 5.478, de 25.7.1968, verbis "A decisão judicial sôbre alimentos não transî̧a em julgado, pode a qualquer momento ser revista em face da modificação da situação financeira dos interessados". Se por "trânsito em julgado" se entende a preclusão das vias recursais, tôda decisão judicial transita em julgado no momento em que se torna irrecorrível. Ora, ninguém dirá que a decisão sôbre alimentos se sujeite indefinidamente a ataque mediante recurso. A possibilidade de revisão, a que alude a parte final do dispositivo, depende da instauração de nôvo processo e nada tem que ver com o trânsito em julgado da decisão no processo anterior. 
vai declinando, mas que até certa época preponderou entre os expositores do nosso processo civil, a dilatar o círculo de incidência da coisa julgada. Tal inclinação explica-se, de um lado, pela persistência de idéias filiadas à célebre teoria de SAVIGNY acêrca dos "motivos objetivos" da decisão; de outro lado, pelo acolhimento demasiado rápido de sugestões que sem dúvida emanam do teor literal do parágrafo único do art. 287 do Código de 1939, verbis "Considerar-se-ão decididas tôdas as questões que constituam premissa necessária da decisão". A plena compreensão dessa norma, entretanto, não pode prescindir dos dados históricos relacionados com a sua inserção no direito positivo brasileiro, a partir do momento em que, pela priveira vez, sob fórmula quase idêntica, fluíra ela da pena de CARNELUTTI, em dispositivo depois incorporado ao Projeto italiano de 1926; e - o que mais importa - enganoso fôra pretender aplicá-la sem levar em conta, ao arrepio da boa hermenêutica, a necessidade de articulação com o preceito do art. $4 .^{\circ}$, a cuja luz fica bem claro que as questões prejudiciais não as decide, pròpriamente, $\circ$ juiz, mas delas conhece incidenter tantum. $\left(^{3}\right)$

Cabe, então, a pergunta: como proceder se, no curso do processo, exsurge o interêsse, de uma ou de outra parte, em obter pronunciamento judicial, com fôrça de coisa julgada, sôbre a relação ou o status lògicamente subordinante? Qual o expediente idôneo a converter a mera quesłão prejudicial em causa prejudicial, que se haja de decidir no mesmo processo em que corre a principal? Pleitear em reconvenção a declaração da existência ou inexistência da relação ou do stałus lògicamente subordinante é via que só ao réu se abre, e ainda assim sob notórias condições limitativas, inclusive de prazo. Fora daí, no direito brasileiro vigente, o caminho único é o do ajuizamento em separado do pedido declaratório, com posterior requerimento de junção dos processos, fundado na conexidade das causas (art. 116).

A ação declaratória incidental parece constituir instrumento mais prático e eficaz para a consecução do fim visado. Consagram-na, entre outras, duas das mais importantes leis processuais em vigor: a Ordenação alemã de 1877 e o Código italiano decretado em 1940. Disciplina aquela no $\S 280$ a Zwischenfeststellungsklage, nestes têrmos: ( $\left.{ }^{4}\right)$ "Até o encerramento da audiência de publicação da sen-

(3) - Para uma cumprida demonstração da tese, v. nosso trabalho Questöes prejudiciais e coisa julgada, Rio, 1967, págs. 96 e segs. À bibliografia aí mencionada acrescente-se MACHADO GUIMARÃES, ob. cit. págs. 20/21.

(4) - Eis o texto original: "Bis zum Schluss derienigen mündlichen Verhandlung, auf die das Urteil ergeht, kann der Kläger durch Erweiterung des Klageantrags, der Beklagte durch Erhebung einer Widerklage beantragen, dass ein im Lavfe des Prozesses streitig gewordenes Rechłsverhälłnis, von dessen Besłehen oder Nichtbestehen die Enîscheidung des Rechtsstreits ganz oder zum Teil abhängt, durch richterliche Entscheidung festgestellt werde". 
tença, o autor, mediante ampliação do pedido, e o réu, mediante reconvenção, podem requerer pronunciamento declaratório sôbre relação jurídica controvertida no curso do processo, de cuja existência ou inexistência dependa, no todo ou em parte, a decisão da lide"; na verdade, como assinala a doutrina $\left({ }^{(5)}\right)$, o pedido de declaração incidente tem lugar até na instância da apelação, desde que a parte contrária nisso convenha, ou o próprio tribunal, julgando útil a providência, Ihe supra o consentimento. O Codice di Procedura Civile, de forma bem menos sistemática, apenas se refere expressamente, no art. 34, a um possível efeito, em hipótese particular, da domanda di accertamento incidentale, dispondo: "se, por fôrça de lei ou por explícito pedido de uma das partes, é necessário decidir com eficácia de coisa julgada questão prejudicial que pertença, em razão da matéria ou do valor, à competência de órgão superior, o juiz remete a êste tôda a causa, assinando às partes um prazo peremptório para a retomada do processo diante dêle" (do juízo primitivo). Em sede doutrinária tem-se versado amplamente a matéria, esforçando-se os autores por suprir a lacônica regulamentação legal.

O Anteprojeto BUZAID opta decididamente pela limitação da auctoritas rei iudicałae ao âmbito da questão principal, estatuindo, no art. 509, que não fazem coisa julgada "os motivos, ainda que importantes para determinar o alcance da parte dispositiva da sentença" (inciso I), nem "as questões prejudiciais, resolvidas incidentemente no curso do processo" (inciso III). Admite, em contrapartida, a ação declaratória incidental, que ministra justamente o meio hábil à obtenção de pronunciamento, com fôrça de res iudicata, sôbre questão de que lògicamente dependa a solução do litígio. Dispersa-se a respectiva disciplina por vários dispositivos - arts. $5 .^{\circ}, 124-\mathrm{n} .^{\circ} \mathrm{IV}$, 354 e 510 -, de cuja conjugação ressaltam os traços característicos do instituto. O pedido de declaração incidental será admissível sempre que, no curso do processo, se tornar controvertido "um direito, de cuja existência ou não dependa a decisão da lide" (art. 5. ${ }^{\circ}$ ) ou, em outras palavras, cuja existência ou inexistência constitua "pressuposto necessário" do julgamento da ação principal (art. 510) -, contanto que o órgão perante o qual esta corre não seja incompetente ratione materiae para a causa prejudicial (art. 510). A declaração incidental far-se-á por sentença (art. 354), evidentemente apta a adquirir a autoridade de coisa julgada, pondo a salvo de futuras contestações, assim, a relação ou o stałus lògicamente subordinante.

Um exemplo concreto, a que já se fêz menção, ilustrará de modo eloqüente a importância prática do instituto. Se Tício pleiteia

(5) - Pcr interpretação sistemática dos §§ 523, 264 e 521, 4.a alínea: v. ROSENBERG, Tratado de Derecho Procesal Civil, trad. esp., Buenos Aires, t. II, pág. 86. 
a condenação de Caio ao pagamento de multa convencional, por suposta violação de contrato, e Caio argúi a nulidade dêste como simples matéria de defesa, a sentença definitiva, ainda que acolha a argüição, julgando portanto improcedente o pedido, não produzirá coisa julgada sôbre a questão prejudicial, mas apenas sôbre a inexistência do crédito que se alegara com base na cláusula penal. Isso significa que Tício pode voltar a juízo para formular contra Caio qualquer outro pedido com fundamento no mesmo contrato, e ao juiz dêsse processo posterior fica livre a apreciação da prejudicial, que poderá ser resolvida em sentido contrário - ou seja, no de reconhecer-se como válido o negócio -, com o conseqüente acolhimento da nova demanda. Se, entretanto, Caio recorrer à ação declaratória incidental, poderá obter, no primeiro processo, decisão com fôrça de res iudicała sôbre a inexistência da obrigação principal, afastando dessa maneira, em caráter definitivo, a viabilidade de subseqüentes investidas, por parte de Tício, com base no contrato declarado nulo.

É indiscutível, assim, a utilidade da inovação trazida pelo Anteprojeto. Sòmente nos parece desejável que, no curso dos trabaIhos de revisão, se dê disciplina mais minuciosa a alguns pontos, para evitar incertezas na aplicação do instituto. O mais importante dêles concerne ao momento em que o órgão judicial haverá de pronunciar-se sôbre o pedido de declaração incidental.

Em princípio, seria ao nosso ver razoável que ambas as decisões - sôbre a questão subordinante e sôbre a questão subordinada se viessem a proferir conjuntamente, em sentença una do ponto de vista formal, embora composta de dois capítulos distintos. Sucede, porém, que o Anteprojeto, aliás louvàvelmente, prevê o julgamento antecipado da lide, com dispensa da audiência, quando a controvérsia de mérito fôr apenas de direito ou, sendo de direito e de fato, não houver necessidade de prova oral (art. 359, n. ${ }^{\circ}$ I). Ora, se $\circ$ pedido de declaração incidental anteceder o instante próprio a êsse julgamento, bem poderá ocorrer que os pressupostos da definição imediata do litígio só estejam caracterizados no tocante à questão subordinante, ou seja, à questão de mérito na ação declaratória incidental. Nada impedirá, então, que o juiz decida desde logo essa questão, reservando a outra para ser apreciada após a instrução suplementar; $\left(^{6}\right)$ a hipótese inversa é que seria inconcebível, dada a relação de dependência lógica necessária existente entre ambas: impossível enunciar a conclusão antes de assentar a premissa. Entretanto, ainda no caso prefigurado, seria inconveniente permitir-se a

(6) - A menos é claro, que a decisão sôbre a causa prejudicial importe desde logo e necessàriamente a definição da lide subordinada, como ocorrerá sempre que se negue a relação jurídica ou $\circ$ stałus de cuija existência dependia o possível acolhimento do pedido inicial. 
imediata interposição de recurso contra a decisão antecipadamente proferida na ação declaratória incidental, com óbvio prejuízo para a marcha do processo. Melhor se nos afigura - e aqui dirigimos a sugestão à preclara Comissão Revisora - dispor expressamente que tal decisão apenas se torne impugnável, em qualquer hipótese, junto com a sentença final.

Com êsses e outros poucos retoques, sobretudo de redação, não sòmente se terá consagrado, no futuro Código de Processo Civil, inovação das mais interessantes, mas até se terá dado ao instituto da ação declaratória incidental disciplina mais requintada do que aquela que lhe imprimem as legislações européias.

3 - O segundo instituto que nos atraiu a atenção relaciona-se com a possibilidade, não raro concretizada na prática judiciária, de que a decisão não proporcione a nenhuma das partes o optimum esperável, surgindo assim para ambas, em linha de princípio, interêsse em recorrer. $O$ caso pode não ser tal, entretanto, que cada qual se sentisse inclinada a aceitar a situação apenas parcialmente desfavorável, resultante do eventual trânsito em julgado. Mas há sempre - risco de que o adversário recorra, e é natural que se pense, de ambos os lados, no inconveniente de permitir que só a parte contrária se ponha em condições de obter - quem sabe? - a reforma da sentença a seu favor. Como não é possível aguardar o escoamento do prazo de interposição, para verificar se ocorreu ou não a temida eventualidade, ambos os litigantes acabam por interpor um recurso de que, no fundo, nenhum fazia muita questão.

Concebem-se dois meios de evitar êsse indesejável resultado. Um dêles consiste em atribuir-se ao recurso de uma das partes o efeito de habilitar o órgão ad quem a reexaminar a decisão também naquilo em que favoreceu o recorrente, reformando-a, se assim the parecer, em benfício do recorrido. O recurso, interposto por qualquer das partes, reputar-se-ia comum a ambas. Tal solução remonta ao direito romano, e mais particularmente a uma constituição do ano 530, pela qual facultou JUSTINIANO ao Tribunal da apelação, se - apelado não comparecesse, corrigir de ofício a injustiça que porventura entendesse contra êle perpetrada pelo órgão a quo. Transmitiu-se ela ao velho direito português, cujas Ordenações consagraram expressamente o princípio da comunhão do recurso, no tocante à apelação:

"Não sòmente proverão os Juízes, que das apelações conhecerem, os apelantes, quando pelos processos acharem, que thes é feito agravo pelos Juízes, de que fôr 
apelado: mas ainda que achem, que o apelante não é agravado, se acharem que ao apelado foi feito agravo, provê-lo-ão, e emendarão seu agravo; pôsto que não seja por êle, nem por seu Procurador apelado, nem alegado êsse agravo perante os Juízes da alçada" (Cód. Filipino, L. III, Tít. LXXII, pr.).

Essa orientação perdurou entre nós, acolhida que foi pelas Consolidações de 1876 e 1898, bem como por vários Códigos estaduais, ao tempo da dualidade de competências para legislar sôbre direito processual. Ainda após a decretação do estatuto nacional de 1939, a voz autorizadíssima de LIEBMAN afirmou a subsistência, em nosso direito, da communio appellationis; mas a doutrina afinal predominante, através da interpretação sistemática dos dispositivos do Código, excluiu a possibilidade da reformatio in peius, pondo o direito positivo brasileiro, no particular, em consonância com a diretriz prevalecente na generalidade das legislações processuais de nossa época. $\left({ }^{7}\right)$

Não há dúvida, porém, que de lege ferenda ressalta a conveniência de contrapor a tal vedação a abertura de ensejo à ampliação da atividade cognitiva do órgão ad quem, em ordem a possibilitar, sendo o caso, a reforma da decisão a favor da parte que originàriamente tenderia a não recorrer. $O$ expediente de que em regra se valem as leis estrangeiras, e que o Anteprojeto pretende introduzir no sistema pátrio, consiste exatamente em permitir que a parte espere o decurso do prazo de interposição, para resolver, à vista da atitude tomada pelo adversário, se impugnará ou não a sentença. Recorrendo um dos litigantes, fica sempre ressalvado ao seu contraditor o direito de recorrer, também, mesmo após o têrmo final de cujo advento, normalmente, Ihe resultaria a preclusão das vias recursais. Êsse segundo recurso, que só terá sido interposto porque o oułro o foi, tem subordinada à dêste, em certa medida, a sua sorte, deixando de produzir qualquer efeito se da primeira impugnação se desistir ou não se vier a conhecer.

Assim é que, no direito alemão, a parte que não recorreu no prazo normal pode "aderir", por meio da Anschlussberufung (Z.P.O., $\S 521$ ) ou da Anschlussrevision (§ 556), à apelação ou ao recurso de cassação interposto pelo adversário. O Código português, no art. 682, depois de estatuir que, "se ambas as partes ficarem vencidas, cada uma delas terá de recorrer se quizer obter a reforma da decisão na parte que lhe seja desfavorável", esclarece que "o recurso por

(7) - V. a discussão da matéria, com exposição e crítica dos argumentos ex utraque parte, em nosso verbête Reformatio in peius, no Repertório Enciclopédico do Direito Brasileiro, vol. 46 - Rio, 1970, especialmente n.0s 3 a 5. 
qualquer delas interposto pode, nesse caso, ser independente ou subordinado" (1. a alínea), e em seguida dispõe que "o recurso subordinado pode ser interposto dentro de cinco dias, a contar de notificação do despacho que admite o recurso da parte contrária" (2." alínea, fine). Tem $\circ$ direito francês, por seu turno, o appel incident, previsto no art. 445-3 do Code de Procédure Civile (redação do Dec. n. ${ }^{\circ}$ 65-1006, de 26-11-1965). Na Itália, o Codice di Procedura Civile em vigor desde 1942 disciplina a figura da impugnazione incidentale, tanto no capítulo relativo aos recursos em geral (arts. 333 e 334), como especificamente no que tange ao appelo (art. 343) e ao ricorso per cassazione (art. 371). E na Espanha, o art. 858 da Ley de Enjuiciamiento Civil permite ao apelado "adherirse a la apelación sobre los puntos en que crea que le es perjudicial la sentencia".

Não nos parece adequado o nomen iuris de "recurso adesivo", que o Anteprojeto consagra na esteira das leis alemã e espanhola. A parte não "adere" à impugnação do adversário, senão que the contrapõe a sua. Ousaríamos sugerir que se falasse, à semelhança do Código português, em "recurso subordinado": essa denominação reflete com fidelidade uma das características essenciais da figura, que é a de ficar o conhecimento, pelo órgão ad quem, condicionado ao da primeira impugnação (Anteprojeto, art. 548, n. ${ }^{\circ}$ IV), e soa mais expressiva que a de "recurso incidental", usada em França e na Itália.

De acôrdo com o art. 548, n. ${ }^{\circ}$ III, do Anteprojeto, o nôvo instituto só terá cabimento na apelação e no recurso extraordinário. Queremos crer que seria razoável estendê-lo ao recurso ordinário constitucional, na única hipótese de admissibilidade que lhe deixou, no campo do processo civil, a Emenda n. ${ }^{\circ} 1$, de 1969 - a saber, nas "causas em que forem partes Estado estrangeiro ou organismo internacional, de um lado, e, de outro, município ou pessoa domiciliada ou residente no país" (art. 119, n. ${ }^{\circ}$ II, letra a). É que na verdade, aí, o recurso ordinário nada mais é do que um sucedâneo da apelação, com a única singularidade de interpor-se diretamente para - Supremo Tribunal Federal.

No mais, a disciplina atribuída pelo Anteprojeto ao "recurso adesivo" não discrepa dos modelos que the oferecia o direito comparado e que entre si guardam substancial afinidade. Os reparos miúdos que se pudessem opor a esta ou àquela fórmula não prejudicariam a impressão global, amplamente favorável ao texto, nesta como em tantas outras matérias.

4 - A respeito da tentativa de conciliação das partes seria me- 
nos exato falar de inovação que de renovação. O instituto era conhecido do velho direito português, como atesta a Ordenação do L. III, Tít. XX, § 1.: "No comêço da demanda dirá o Juiz a ambas as partes, que antes que façam despesas, e se sigam entre elas os ódios e dissensões, se devem concordar, e não gastarem suas fazendas por seguirem suas vontades, porque o vencimento da causa sempre é duvidoso". Recebeu-o, pois, o Brasil, ao encetar sua vida independente, e a Constituição do Império, art. 161, indo adiante do Código Filipino, em que ela era faculłałiva, tornou até obrigatória a tentativa de conciliação; "Sem se fazer constar que se tem intentado o meio da reconciliação, não se começará processo algum". Tocava aos juízes de paz a competência para êsse procedimento prévio (art. 162), que o Regulamento n. 737 disciplinou minuciosamente, com relação às causas comerciais (arts. 23 a 38). Tais dispositivos não chegaram a aplicar-se aos feitos civis, e pouco depois de proclamada a República o Dec. n. ${ }^{\circ} 359$, de 1890, aboliria a tentativa de conciliação como formalidade preliminar essencial. A experiência brasileira atual, no terreno do processo civil, restringe-se às ações de desquite e de alimentos (Lei n. ${ }^{\circ}$ 968, de 10-12-1949, art. $1 .^{\circ}$; Lei n. ${ }^{\circ} 5.478$, de 25-7-1968, art. $\left.9 .^{\circ}\right)$.

São famosas as discussões entre filósofos e reformadores políticos e sociais acêrca das vantagens e desvantagens da tentativa de conciliação. Dos panegíricos de VOLTAIRE às diatribes de BENTHAM, pràticamente| todos os juízos já se emitiram ao propósito. Sem pretendermos enfrentar o problema em nível teórico, mas atendo-nos de caso pensado a perspectiva mais modesta e imediata, observaremos apenas que a utilidade prática do i istituto acha eloqüente demonstração no simples fato de sua subsistência em quase todas as modernas legislações processuais civis. Prevêem, com efeito, a tentativa de conciliação, em têrmos facultativos, o código francês (art. 81-3, com a redação do Dec. n. ${ }^{\circ}$ 65-872, de 13-10-1965) e o alemão (§ 296); com caráter obrigatório, o austríaco ( $§ 239,2^{\text {a }}$ alínea), o espanhol (art. 460), o italiano (arts. 185 e 350, 3. a alínea) e o português (arts. 508 e 509). No direito brasileiro, mesmo, se são discutíveis os resultados colhidos nas ações de desquite e de alimentos, existe todavia um campo em que a tentativa de conciliação se vem firmando, já há longos anos, como experiência proveitosa e digna de atenção: o processo trabalhista.

Conforme revelam as lições do direito comparado e a própria tradição nacional, a diretriz predominante na matéria tem sido a de fazer promover a tentativa de conciliação em momento anterior à instauração do processo, ou pelo menos na fase inicial do respectivo 
desenvolvimento. Presume-se que ocorra aí o instante psicològicamente mais favorável à obtenção do consenso das partes, às quais se apresenta uma oportunidade de composição que lhes evitará os incômodos e as despesas do procedimento judicial. Tem-se entendido que diminuem as probalidades do acôrdo na mesma proporção em que, com o desenrolar do processo, o fogo cruzado das increpações exaspera ressentimentos e suscita nos litigantes a impressão de que prosseguir até o fim, a qualquer preço, é quase um ponto de honra. Tal observação não parece anular-se à vista da outra, que às vêzes se lhe contrapõe, e segundo a qual é só ao fim da atividade instrutória que cada uma das partes se põe em condições de prever com alguma segurança o desfecho do pleito: se é verdade que a perspectiva de uma derrota quase certa pode predispor à conciliação o litigante menos favorecido pelas provas, por outro lado é inegável que a expectativa da vitória próxima as mais das vêzes produzirá efeito inverso no adversário - e a tentativa, para ter êxito, reclama a bilațeralidade do ânimo conciliatório... Do ponto-de-vista da economia processual, ademais, imensamente preferível será a solução que enseje o truncamento da atividade judicial antes do dispêndio de energias indispensável, em regra, à instrução da causa.

Merece pois reexame, ao nosso ver, a opção, feita pelo Anteprojeto, de reservar a tentativa de conciliação para a fase final do procedimento de primeira instância. Quando muito, poderia admitirse que $\circ$ juiz, antes de proferir a decisão, reiłerasse a exortação ao acôrdo, porventura anteriormente frustrada, à semelhança do que se dá no processo dos dissídios individuais de trabalho (C.L.T., art. 850, caput, 2..$^{\circ}$ parte). Mas isso sem prejuízo da tentativa in limine litis - até porque, segundo já observou o Professor MONIZ DE ARAGÃO, $\left.{ }^{8}\right)$, jamais teria ela ocasião de realizar-se, a não ser assim, nos processos em que ocorra o julgamento antecipado da lide, com dispensa da audiência (Anteprojeto, art. 359).

Injustificável, por outro lado, a limitação do âmbito de aplicabilidade do instituto aos litígios que versarem "sôbre direitos patrimoniais de caráter privado" (Anteprojeto, art. 485). Basta lembrar que, iá no sistema vigente, a tentativa de conciliação é de rigor nas ações de desquite. $O$ que se deve exigir é tão sòmente que se trate de relações jurídicas acêrca das quais tenham as partes poder de disposição. O preceito restritivo do Anteprojeto denota uma exagerada acentuação da afinidade entre o acôrdo realizado por esta via e a transação tal como a regula o Código Civil (cf. 1.035), confor-

(8) - Estudos sôbre a reforma processual, Curitiba, 1969 - pág. 59. 
me ressalta do próprio emprêgo da palavra "transação" nos arts. 486 e 487. Mas os dois institutos, se por alguns aspectos se assemelham, certamente não se identificam, bastando lembrar que, ao contrário da transação (Código Civil, art. 1.025), a conciliação não implica necessàriamente "concessões mútuas".

Deslocada que seja para a fase inicial do processo a tentativa de conciliação, como nos parece aconselhável, valerá a pena considerar-se a possibilidade de mais amplo aproveitamento da audiência destinada a promovê-la, para que não fique perdida a atividade processual, na hipótese de frustrar-se o acôrdo. Se nessa mesma ocasião se pudesse conhecer das defesas preliminares, ou pelo menos de uma parte delas, ter-se-ia conseguido vantagem dupla do ponto-de-vista da economia processual. De um lado, atalhar-se-ia desde logo a marcha do feito, em casos nos quais se tornasse de imediato evidente a inviabilidade da consumação normal representada pela emissão de sentença definitiva. De outro lado, repelir-se-iam com igual presteza, e manifesto proveito para a ordem do processo, as argüições inconsistentes, feitas não raro com óbvio intuito protelatório. Tantas alegações de incompetência, ou de litispendência, ou de coisa julgada, ou mesmo de ilegitimidade de parte, que às vêzes se formulam ùnicamente para procrastinar a decisão, ou tumultuar o feito, ou desviar do essencial a atenção do juiz, poderiam talvez ser apreciadas de plano, desde que já presentes todos os indispensáveis elementos de convicção; e até ousamos crer que algumas nem se chegariam a formular, se tivesse o réu de fazê-lo oralmente, em face do juiz e do autor... Em nosso processo trabalhista, a própria defesa de mérito deve ser oferecida na mesma audiência em que se tenha a conciliação. Sem avançarmos até êsse ponto, gostaríamos de ver examinada - e aqui vai outra sugestão para a douta Comissão Revisora - a idéia de retomar-se, com os necessários retoques e adaptações, uma experiência abonada pelo exemplo da Áustria, onde a primeira audiência (erste Tagsałzung), além da tentativa de conciliação, enseja o suscitamento de várias questões preliminares (Z.P.O., § 239), sôbre as quais pode o juiz desde logo pronunciar-se.

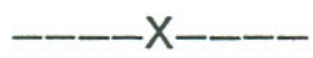

O Anteprojeto BUZAID corresponde em larga medida ao generalizado anseio pela renovação do processo civil brasileiro. A todos é lícito, evidentemente, discordar de tal ou qual solução encontrada para cada um dos inúmeros problemas, de ordem técnica e de ordem prática, que ao seu ilustre autor se depararam. A imprescindí- 
vel elaboração crítica, que já tem aliás produzido bons frutos, e que decerto ministrará valiosos subsídios para a tarefa de revisão entregue às mãos competentes de três exímios juristas - os Professôres MACHADO GUIMARÃES e JOSÉ FREDERICO MARQUES e o Desembargador LUÍS ANTÔNIO DE ANDRADE - pressupõe naturalmente 0 estudo atento de um texto que tão saborosas oportunidades abre de comentário e debate. A reformulação sistemática é ampla e, como não podia deixar de ocorrer, em diversos tópicos polêmica. Altera-se de modo sensível a estrutura do processo de conhecimento, sobretudo no que tange ao sistema de recursos; dá-se configuração profundamente diversa a institutos como $\circ$ da intervenção de terceiros e o das medidas cautelares; unifica-se o processo de execução. regulando-se em conjunto a atividade executiva fundada em sentença e a fundada em título extrajudicial; cria-se modalidade especial de execução coletiva, no caso de insolvência do devedor - verdadeira falência civil, sem o nome. Et j'en passe...

Tudo isso está a merecer, e quase diríamos a reclamar, a atenção dos interessados, que afinal somos todos - professôres, juízes, advogados ou simples cidadãos. É imperioso que se divulgue $\circ$ Anteprojeto, até como condição sine qua non do seu eventual aperfeiçoamento, que pode e deve resultar da colaboração geral. Para essa tomada de consciência quisemos contribuir, ainda que modestamente, com as achegas hoje propostas à consideração do egrégio auditório. Outros, com maior autoridade, hão de prosseguir no trabalho. 